NBER WORKING PAPER SERIES

\title{
WHAT ARE THE RESULTS OF PRODUCT- PRICE STUDIES AND WHAT CAN WE LEARN FROM THEIR DIFFERENCES?
}

\author{
Matthew J. Slaughter
}

Working Paper 6591

http://www.nber.org/papers/w6591

\section{NATIONAL BUREAU OF ECONOMIC RESEARCH 1050 Massachusetts Avenue \\ Cambridge, MA 02138 \\ June 1998}

This paper has been prepared for the forthcoming National Bureau of Economic Research conference volume "The Impact of International Trade on Wages." For helpful comments I thank Robert Baldwin and participants at this volume's official conference. Also, for financial support I thank the Russell Sage Foundation for support through grants \#85-96-18 and \#85-97-18. Any opinions expressed are those of the author and not those of the National Bureau of Economic Research.

(C) 1998 by Matthew J. Slaughter. All rights reserved. Short sections of text, not to exceed two paragraphs, may be quoted without explicit permission provided that full credit, including $@$ notice, is given to the source. 
What Are the Results of Product-Price Studies

and What Can We Learn From Their Differences?

Matthew J. Slaughter

NBER Working Paper No. 6591

June 1998

JEL Nos. F16, J31

\section{ABSTRACT}

In recent years many economists have analyzed whether international trade has contributed to rising U.S. wage inequality by changing relative product prices. In this paper I survey the findings of nine "product-price" studies which together demonstrate how the methodology of product-price studies has evolved. I then synthesize the findings of these nine studies and draw two main conclusions. The first conclusion is that this literature has a refined set of empirical strategies for applying the Stolper-Samuelson theorem to the data from which important methodological lessons can be learned. The second main conclusion is that despite the methodological progress that has been made, research to date still has fundamental limitations regarding the key question of how much international trade has contributed to rising wage inequality. Most importantly, more work needs to link exogenous forces attributable to international trade to actual product-price changes.

Matthew J. Slaughter

Department of Economics

Dartmouth College

309 Rockefeller Hall

Hanover, NH 03755

and NBER

slaughter@dartmouth.edu 


\section{Introduction}

In recent years many economists have analyzed whether international trade has contributed to rising U.S. wage inequality by changing relative product prices. In this paper I survey and synthesize the findings of these "product-price" studies.

The theoretical framework guiding this research is the Stolper-Samuelson (SS) theorem linking product-price changes to factor-price changes. The research discussed in this paper constitutes the first large body of empirical work applying the SS theorem to the data. Before these studies there was relatively little empirical research on the SS theorem. Deardorff's (1984) chapter in the Handbook of International Economics entitled "Testing Trade Theories and Predicting Trade Flows" does not cite a single empirical study of it. And in a famous book commemorating the 50th anniversary of the landmark paper by Stolper and Samuelson (Deardorff and Stern (1994)), of the ten essays reprinted as "seminal contributions to the Stolper-Samuelson literature" (p. 5) only one is empirical (Magee (1980)).

My survey and synthesis of the product-price studies has three parts. First, borrowing language from Deardorff (1994) I lay out several theoretical statements of the SS theorem to preview some of the empirical issues involved in applying it to data.

Second, I survey the "product-price" studies on rising U.S. wage inequality. In chronological order I cover the following papers: Bhagwati (1991), Lawrence and Slaughter (1993), Sachs and Shatz (1994), Feenstra and Hanson (1995), Leamer (1996), Baldwin and Cain (1997), Krueger (1997), Feenstra and Hanson (1997), and Harrigan and Balaban (1997). Together these nine studies demonstrate how the methodology has evolved. By surveying these papers chronologically I can relate each study to those preceding it.

Finally, I synthesize the findings of these nine studies and draw two main conclusions. The first conclusion is that this literature has refined a set empirical strategies for applying the SS theorem to the data from which important methodological lessons can be learned. To preview some of the main results, "the facts" about product prices are relatively sensitive to the selection 
and weighting of industries sampled and to the decade considered. In contrast, "the facts" are relatively insensitive to the extent of data aggregation and the measurement of skills.

The second main conclusion is that despite the methodological progress that has been made, research to date still has fundamental limitations regarding the key question of how much international trade has contributed to rising wage inequality. Most importantly, more work needs to link the various exogenous forces attributable to international trade to actual product-price changes. Stated alternatively, the literature to date has made substantial progress understanding how to relate a given change in relative product prices to changes in relative factor prices. But it has made less progress understanding whether these product-price changes have anything to do with international trade. Two other important areas needing further work are the need to explore how slowly the Heckscher-Ohlin clock ticks and the need to complement product-price data with other data that might overcome potential limits of the product-price data.

The rest of the paper is organized as follows. Section 2 presents the theoretical framework for understanding the product-price studies. Section 3 surveys each of the nine studies cited above. Section 4 synthesizes these studies and highlights the overall methodological progress. Section 5 discusses the limitations of these studies. Section 6 concludes.

\section{Theory Guiding the Data: Alternative Statements of the Stolper-Samuelson Theorem}

Deardorff (1994) surveys alternative statements of the SS Theorem that have appeared during the past 50-plus years. Each articulation requires a different set of assumptions and thus applies to different contexts. Below I quote (verbatim) Deardorff's six different versions. This list serves two purposes. First, it provides some theoretical context for judging how well researchers have related theory to data. Second, it previews some of the major empirical issues that researchers have had to address.

- GeneralVersion: An increase in protection raises the real wage of the scarce factor of production and lowers the real wage of the abundant factor of production.

- Restrictive Version: Free trade lowers the real wage of the scarce factor and raises that of the abundant factor compared to autarky. 
- Essential Version: An increase in the relative price of a good increases the real wage of the factor used intensively in producing that good and lowers the real wage of the other factor.

- Strong Version with Even Technology: A rise in the price of any good, all other prices remaining constant, causes an increase in the real return to the factor used intensively in the producing that good and a fall in the real returns to all other factors.

- Friends and Enemies Version: Every good is a friend to some factor and an enemy to some other factor.

- Correlation Version: For any vector of goods price changes, the accompanying vector of factor price changes will be positively correlated with the factorintensity-weighted averages of the goods price changes.

Deardorff very clearly discusses the theoretical relationships among all six versions; the interested reader is strongly encouraged to read this discussion. To complement this, I make four points about applying these versions to the empirical issue of rising wage inequality.

First, only two of the versions mention anything about international trade. This underscores that the essence of all SS versions is the link between product prices and factor prices imposed by the "zero-profit conditions" equating price with average cost that must hold in all perfectly competitive industries with actual production. ${ }^{1}$ These zero-profit conditions imply a systematic relationship between the entire set of product prices facing domestic producers and the entire set of factor prices paid by these producers. Analytically, the economy's entire set of zero-profit conditions can be written as follows:

$$
\text { (1) } \mathrm{P}=\mathrm{A} \times \mathrm{W} \text {, }
$$

where $\mathrm{P}$ is an ( $\mathrm{N} \times 1)$ vector of $\mathrm{N}$ domestic product prices, $\mathrm{W}$ is an ( $\mathrm{M} \times 1)$ vector of $\mathrm{M}$ domestic factor prices, and $\mathrm{A}$ is an ( $\mathrm{N} \times \mathrm{M}$ ) technology matrix (which might also depend on $\mathrm{W}$ ) whose $\mathrm{a}_{\mathrm{ij}}$ element tells the number of units of factor i required to produce one unit of product $j$. Each row of equation (1) corresponds to one of the $\mathrm{N}$ products, and in words the equation says for each product price equals average costs. Importantly, notice that factor prices are not indexed by

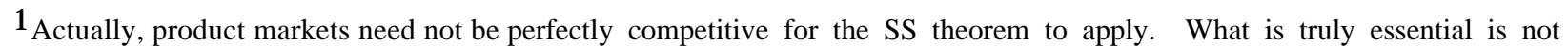
perfect competition but rather the existence of a systematic link between product prices and factor prices. Perfect competition is only one way of obtaining this "systematic link": it restricts price to be just equal to average cost. An alternative might be imperfect competition which fosters a positive--but unchanging--price-cost markup. Another alternative analyzed extensively in Helpman and Krugman (1985) is monopolistic competition in which sufficient entry by new firms ensures zero profits in equilibrium.
} 
industry: with the assumption of perfect interindustry factor mobility each factor has only one national price. This is a key aspect of all versions of the SS theorem.

Holding constant technology, equation (1) can be rewritten in terms of percentage changes for (sufficiently small) changes. This yields the following equation:

$$
\text { (2) } \mathrm{P}^{*}=\theta \times \mathrm{W}^{*} \text {, }
$$

where $\mathrm{P}^{*}$ is an $(\mathrm{N} \times 1)$ vector of $\mathrm{N}$ domestic product-price changes, $\mathrm{W}^{*}$ is an $(\mathrm{M} \times 1)$ vector of $\mathrm{M}$ domestic factor-price changes, and $\theta$ is an $(\mathrm{N} \times \mathrm{M})$ initial cost-share matrix (which depends on technology and, perhaps, W) whose $\theta_{\mathrm{ij}}$ element tells the share of factor $\mathrm{i}$ in the average costs incurred producing one unit of product j. ${ }^{2}$ Changes in product prices faced by domestic firms generate changes in domestic factor prices paid by firms as described by equation (2). This is true whether product-price changes are caused by international trade or any other force. Indeed, many SS versions apply even to countries in autarky with all products nontraded. The empirical implication of this is the need for a way to determine what portion of observed product-price changes are attributable to international trade. Equation (2) will be an important reference point.

It is worth emphasizing that the phrase "caused by international trade" needs to be treated carefully. As Deardorff and Haikura (1994) discuss, this phrase can be misleading in that international trade--i.e., the flows of goods and services across countries--is the endogenous outcome of (among other things) international differences in tastes, technology, endowments, and barriers to trade. International trade and product prices are simultaneously caused by things; trade does not cause product-price changes. Thus attributing causality from international trade to domestic product prices requires a bit more precise language. Specifically, it requires reference to some aspect of the international-trade equilibrium that can be plausibly taken as exogenous to domestic product prices.

\footnotetext{
${ }^{2}$ Note that going from equation (1) to equation (2) uses the fact that cost minimization implies that $\mathrm{dA} \times \mathrm{x}=0$. This says that any small changes in factor usage must not change costs given that costs were initially minimized.
} 
Following Deardorff and Haikura, I propose four different restatements of the phrase "international trade can change domestic product prices," each of which elaborates on "international trade.".

- (1) "A change in domestic political barriers to trade can change domestic product prices."

- (2) "A change in foreign political barriers to trade can change domestic product prices."

- (3) "A change in international natural barriers to trade can change domestic product prices."

- (4) "A change in foreign tastes, technology, and/or endowments can change domestic product prices."

Think of domestic product prices as depending both on "international" product prices and on any trade barriers that wedge between international and domestic prices. If the country is "small" then international prices are independent of domestic trade barriers and other parameters. Otherwise, domestic trade barriers and other domestic parameters do affect international prices. Given this setup, statements (1) through (3) address how domestic prices depend on the wedge--and, if the country is large, on international prices as well. Statement (4) addresses how domestic prices depend on developments abroad communicated to the domestic economy through changes in international prices.

Overall, to meaningfully analyze whether "international trade changes product prices" one must have sufficient data to restate the issue something like one of these four statements. Without some data on trade barriers, tastes, technology, and endowments, actual price changes cannot be empirically linked to some exogenous aspect of international trade.

A second key point about Deardorff's six SS versions is that the best guide for empirical work depends on the world's dimensionality. The first three versions hold only in worlds with two factors and two products. The Strong Version holds only for worlds with the same number of factors and products (more than two allowed) and only under certain technology restrictions. Only the last two versions hold for any arbitrary number of factors and products. If one thinks that the world cannot be reasonably approximated as $2 \times 2$ then one should focus on the latter three versions. If one is uncomfortable assuming the world is even then one should focus on the last two versions. 
The third key point is that only the Correlation Version directly addresses something other than real-wage changes. This matters because all nine product-price studies surveyed below focus on rising inequality, not the absolute losses of the less-skilled. ${ }^{3}$ In light of the discussion regarding dimensionality, this point suggests that the Correlation Version might be the best guide for empirical work on relative wages. Friends and Enemies focuses on the price change of only a single product, and it claims only that that single price change will raise the real return to one unidentifiable factor an lower the real return of some other unidentifiable factor. In contrast, the Correlation Version relates any vector of relative product-price changes and allows these changes to be systematically related to relative factor-price changes to relative factor prices. Granted, one cannot predict for certain what will happen to any particular relative factor price. But one can say that "on average," factors employed intensively in rising- (falling-) price industries will experience relative price increases (declines). This result seems closest in spirit to the empirical issue of rising wage inequality.

The fourth key point is that all six SS versions do not consider intermediate inputs. In reality intermediate inputs matter a lot: for nearly 40 years, in U.S. manufacturing input purchases have accounted for well over $50 \%$ of the value of final shipments. Accordingly, any empirical work must account for the fact that firms hire both primary factors and intermediate inputs. Rewriting equation (1) to account for intermediate inputs suggests alternative ways of doing this. Define matrix $\mathrm{B}$ as the $(\mathrm{N} \times \mathrm{N})$ matrix of intermediate input requirements whose $b_{\mathrm{ij}}$ element tells the number of units of intermediate input $i$ required to produce one unit of product $j$. Then the set of zero-profit conditions in (1) can be rewritten as follows.

$$
\text { (3) } \mathrm{P}=\mathrm{B} \times \mathrm{P}+\mathrm{A} \times \mathrm{W}
$$

Equivalently, these zero-profit conditions can be rewritten two other ways:

$$
\begin{gathered}
\text { (3') } P=\left[(I-B)^{-1} \times A\right] \times W \\
\left(3^{\prime \prime}\right)(P-B P)=A \times W,
\end{gathered}
$$

\footnotetext{
${ }^{3}$ It is also true that most less-skilled workers have suffered real-wage declines in recent decades. For many less-skilled workers the declines have been staggering: for example, the real hourly earnings of high-school-educated males fell by $20 \%$ from 1979 to 1993.
} 
where $\mathrm{I}$ is an $(\mathrm{N} x \mathrm{~N})$ identity matrix.

This suggests two alternative ways to account for intermediate inputs when linking product prices to factor prices. Following equation (3'), one can measure factor usage not in direct terms but rather in total terms accounting both for direct factor usage and indirect factor usage through intermediate inputs. That is, one can relate factor prices to $\left[(\mathrm{I}-\mathrm{B})^{-1} \mathrm{x} \mathrm{A}\right]$ rather than just to A. Alternatively, following equation (3") one can continue using just direct factor usage as regressors but construct the regressand to be gross-output prices less input prices weighted by the B matrix.

To summarize this theoretical preview of the empirical work, these alternative versions of the SS theorem provide some helpful guideposts. Assume, as most researchers have, that the U.S. economy has less-than-free trade with abroad, more than two products and two factors, and intermediate inputs. Given these assumptions, the most appropriate version of the SS theorem for guiding empirical work is probably the Correlation Version. That is, for any given change in product prices and factor prices consistent with equation (2), in the data one should try to demonstrate the following.

\section{(4) $\operatorname{Cor}\left(\mathrm{P}^{*}, \theta \times \mathrm{W}^{*}\right)>0$}

All this requires a substantial amount of data. In terms of the "explanatory variable," one needs some systematic way to identify the effect of one or more exogenous characteristics of "international trade" on domestic product prices while controlling for non-trade influences on these prices. To identify how this exogenous force of international trade affects relative wages, one also needs industry-level data on domestic product prices and on the prices and quantities of inputs and factors employed.

\section{A Survey of Nine Product-Price Studies}

In this section I cover in chronological order the following product-price studies: Bhagwati (1991), Lawrence and Slaughter (1993), Sachs and Shatz (1994), Feenstra and Hanson (1995), Leamer (1996), Baldwin and Cain (1997), Krueger (1997), Feenstra and Hanson (1997), and Harrigan and Balaban (1997). Together, these papers demonstrate how the methodology of product-price studies has evolved. Where appropriate, other related papers will be mentioned. By 
surveying these nine papers chronologically I can relate each to the relevant work preceding it. For each paper I refer the interested reader to exact pages with the key results.

Bhagwati (1991) is the first researcher I am aware of to link rising U.S. wage inequality to international trade working through product prices. He plots (Figure 7, p. 51) quarterly observations from 1982 through 1989 of the U.S. price indexes for exports and imports of all manufactures aggregated together. Observing that import prices rose more quickly than the export prices after 1986, Bhagwati concludes that "the trade-focused explanation [of rising wage inequality thanks to declining relative prices of imported products which presumably employ lessskilled labor relatively intensively] ... therefore carries little plausibility, at least at first blush."

Lawrence and Slaughter (LS) (1993) are the first researchers to use price data disaggregated by industry and also direct measures of industry factor usage. They use three different sets of U.S. manufacturing prices: imports, exports, and domestic production. The export and import prices cover all industries at the two-digit and three-digit SIC level for which the Bureau of Labor Statistics assembles the data. These data do not cover all manufacturing industries: for example, the import prices cover 18 of the 20 two-digit SIC industries but only about 50 of the 143 threedigit SIC industries. LS assume (fn. 55, p. 195) "that the price movements in these industries are reasonably representative" of all industries. The domestic prices cover all three-digit SIC industries. LS refer to the traded prices as "international prices" whose "changes ... [are] prompted by international trade" (pp. 198-199). Thus, they model the United States as a small price-taking economy facing product prices determined exogenously abroad. For domestic prices LS assume (fn. 63, p. 202) that "changes in these domestic price deflators tracked changes in international prices. This is a weaker assumption than the law of one price: it allows prices to differ across countries by some fixed constant," presumably due to U.S. trade barriers. Because LS assume that all product-price changes come from foreign developments, when analyzing industry differences in total-factor-productivity (tfp) growth, they assume that U.S. technology changes do not influence product prices (p. 199). 
For each price sample LS test whether over the 1980s--defined as 1980 through 1989--the prices of skilled-labor-intensive products rose relative to the prices of unskilled-labor-intensive products. Each industry's skill intensity is measured as the industry's direct employment ratio of nonproduction to production workers (i.e., NPW/PW). LS identify the pattern of price changes two ways. First, (Figures 8 and 9, pp. 196-197) they pool all industries in each price sample and regress industries' percentage change in product prices over the 1980s against industries' skill intensity in 1980. That is, they estimate via OLS the following regression.

$$
\text { (LS) } \mathrm{P}_{\mathrm{j}}{ }^{* 1980 \mathrm{~s}}=\alpha+\beta(\mathrm{NPW} / \mathrm{PW})_{\mathrm{j}}{ }^{1980}+\mathrm{e}_{\mathrm{j}}
$$

Second, to complement these regressions for each price sample they construct a weighted average of all decadal price changes using nonproduction-employment weights and then productionemployment weights (Tables 3 and 4). For the domestic prices LS also construct these weighted averages for the 1970s and 1960s as well.

The basic finding by LS is they estimate $\beta$ to be zero or negative, not positive, for their various series of traded prices: industries with higher relative direct employment of nonproduction to production workers did not have larger price increases over the 1980s. These estimates are corroborated by the weighted averages. LS interpret these results as evidence against the hypothesis that international trade contributed to rising U.S. wage inequality by raising the relative price of skilled-labor-intensive products.

Sachs and Shatz (SSh) (1994) follow the LS methodology with two minor changes and one major change. First, they time the decade of the 1980s as 1978 through 1989. Second, they use a slightly different dependent variable: they share of production employment in total industry employment. Their major difference from LS is the treatment of the computer industry (SIC 357 at the three-digit level, SIC 3573 at the four-digit level). They argue (p. 37) that LS "should have separated the effects of computer prices from the other sectors." The reason is that the computerindustry price data are exceptionally mismeasured: "The relative prices of computers fell sharply during the decade, matching extraordinary productivity increases. The exact measurement of these price and productivity changes is highly problematic, so that it is important that these changes do 
not overwhelm the message in the rest of the data." Thus, using both import prices and the full sample of three-digit SIC domestic prices, SSh run the following regression using OLS.

$$
(\mathrm{SSh}) \mathrm{P}_{\mathrm{j}}{ }^{* 1980 \mathrm{~s}}=\alpha+\beta(\mathrm{PW} /(\mathrm{PW}+\mathrm{NPW}))_{\mathrm{j}}{ }^{1980}+\beta_{\mathrm{c}}\left(\mathrm{D}_{\text {computers }}\right)+\mathrm{e}_{\mathrm{j}}
$$

The main results from these regressions (Table 16, p. 38) are $\beta$ is estimated to be negative (insignificantly so for import prices, significantly (with a t-statistic of -1.98) for domestic prices) while $\beta_{\mathrm{c}}$ is also estimated to be negative (very significantly so (t-statistic of -13.40) for domestic prices). Thus, SSh find among the non-computer sample that industries employing a larger share of production workers had lower relative-price increases over the 1980s. SSh conclude this supports the hypothesis that international trade contributed to rising U.S. wage inequality by raising the relative price of skilled-labor-intensive products.

Unlike the previous three papers, Feenstra and Hanson (FH) (1995) analyze the data from a Ricardian perspective rather than a Heckscher-Ohlin perspective. In their framework countries make completely different sets of products, unlike the Heckscher-Ohlin framework where all countries are (usually) assumed to be in the same cone of diversification. Importantly, FH are the first researchers to move away from the assumption that U.S. prices merely reflect international prices for the same products. They highlight the fact that during the 1980s (defined as 1980 through 1989) in the United States, Germany, and Japan, domestic prices rose by more than import prices did (pp. 17-18 and Table 1). This fact is consistent with their model of international outsourcing which raises wage inequality both in the United States and abroad (Proposition 3, p. 16). As marginal production activities relocate from the United States to abroad the relative demand for skills rises in both countries. A corollary of this shift is that U.S. prices rise by more than foreign prices. Thus if one interprets U.S. import prices as representative of the basket of "foreign" production, the fact about domestic vs. import prices is consistent with outsourcing raising U.S. (and foreign) wage inequality.

Leamer (1996) uses a Heckscher-Ohlin perspective to analyze the wage implications of product-price shifts during the 1960s (1961 to 1971), 1970s (1971 to 1981), and 1980s (1981 to 1991). The data analysis has a descriptive component where "the empirical facts are presented 
with only a 'light' touch of the HO framework" (p. 15) followed by a "formal data analysis ... which is based explicitly on the one-cone HO model" (p. 15).

Leamer's descriptive analysis tracks domestic product prices for two-digit industries relative to the overall producer-price index (PPI) (Figures 10 and 14). The key sectors are textiles and apparel, two very labor-intensive industries. Leamer reports that the three decades behaved very differently. During the 1960s the prices of textiles and apparel fell relative to the overall PPI by a relatively modest $8 \%$ and $4 \%$, respectively. During the 1970 s their relative prices plunged by $30 \%$. Finally, during the 1980 s their relative prices were quite stable. The key message from these descriptive facts are that the 1970s, not the 1960s or 1980s, appear to be the decade where U.S. relative prices of less-skilled-labor-intensive products fell markedly.

For his more structural analysis Leamer uses the zero-profit conditions written above in equation (1). In differentiating these equations to express them in terms of changes, however, Leamer does not assume away changes in technology and their possible feedback to prices--he explicitly allows these changes in his framework. Thus, along with Baldwin and Cain Leamer is one of the first researchers to consider causes of product-price changes other than some aspect of "international trade." Differentiating equation (1) for (sufficiently small) changes while allowing technological progress yields the following equation:

$$
\text { (2') } \mathrm{P}^{*}=\theta \times \mathrm{W}^{*}-\mathrm{TFP}^{*} \text {. }
$$

Here $\mathrm{P}^{*}$ is defined as earlier as an $(\mathrm{N} \times 1)$ vector or product prices; $\theta$ and $\mathrm{W}^{*}$ now include both primary factors and intermediate inputs; and TFP* is an (N x 1) vector of total-factor-productivity (tfp) growth in all industries.

As equation (2') indicates, technological progress can affect equilibrium prices for products and/or factors. The key question is how much does technological progress feed into product-price declines? Consistent with their assumption of the United States being a small price-taking economy, LS assumed zero pass through from tfp growth to product prices. Leamer explicitly relaxes this assumption by considering pass-through rates (identical across all industries) of both zero and one from technological progress to value-added product prices (i.e., $\mathrm{P}$ less the cost-share- 
weighted prices of intermediate inputs). Having controlled for some effect of tfp on product prices, Leamer then assumes that the amount of actual product-price changes not accounted for by technological progress can be attributed to what he terms "globalization." He does not attribute these globalization price changes to anything more specific such as trade barriers or foreign developments communicated to U.S. product prices through the U.S. terms of trade.

Leamer thus distinguishes two forces affecting U.S. factor prices: technological progress and globalization price changes. The relative magnitude of these forces depends on how large a passthrough coefficient from technology to product prices is assumed. Leamer uses regressions to estimate a link from these forces to factor prices. For technology changes Leamer pools all industries to estimate the following,

$$
(\mathrm{L}-\mathrm{T})\left[(1-\lambda) \times \mathrm{TFP}_{\mathrm{j}}{ }^{*}\right]=\left(\theta_{\mathrm{ij}}\right) \beta_{\mathrm{it}}+\mathrm{e}_{\mathrm{j}},
$$

where $\lambda$ is the pass-through coefficient from technology to value-added product prices. Similarly, for "globalization" price changes Leamer pools all industries to estimate the following,

$$
\text { (L-G) }\left[P_{j}^{*}+\left(\lambda \times \text { TFP }_{j}^{*}\right)\right]=\left(\theta_{i j}\right) \beta_{i g}+e_{j},
$$

where $\mathrm{P}_{\mathrm{j}}^{*}+\left(\lambda \times \mathrm{TFP}_{\mathrm{j}} *\right)$ is the vector of globalization price changes.

In both equations (L-T) and (L-G) Leamer interprets the parameter estimates as "mandated" factor-price changes. "These are the changes in factor costs that are needed to keep the zero profits condition operative in the face of changes in technology [i.e., $\mathrm{B}_{\mathrm{it}}$ ] and product prices [i.e., $\mathrm{B}_{\mathrm{ig}}$ ]" (p. 23). Stated differently, the regressions estimate the factor-price changes mandated by changes in technology and/or product prices to maintain zero profits in all sectors. The error term in each equation allows the zero-profit conditions not to bind exactly (for whatever unspecified reasons). Because the econometric fit is not perfect, the mandated factor-price changes can be interpreted as the changes "consistent with the least change in profits in the economy" (p. 29). These mandated factor-price estimates $B_{i t}$ and $B_{i g}$ can then be compared with actual factor-price changes. "If the two conform adequately, we will argue that we have provided an accurate explanation of the trends in wages" (p. 23). Thus the parameter estimates are "tested" by directly comparing them with actual data. Overall, these regressions can be interpreted as an accounting exercise. What changes 
in factor prices are mandated from the observed changes in technology and/or product prices--and what share of actual changes do these mandated changes explain?

In his regressions intermediate inputs are measured as materials purchased. For primary factors he uses capital and either labor or labor disaggregated between more-skilled and less-skilled workers. Leamer measures skills two different ways. One is the classification between nonproduction and production workers. Concerned that this measure excessively misclassifies actual skills, Leamer constructs an alternative skill ranking of industries based on their average earnings per worker (higher average earnings are translated into a higher mix of more-skilled workers). Changes in product prices and technology are the annualized changes over the decades defined above, and cost shares are measured for the first year of each decade. In equation (L-T) Leamer assumes that technological progress affects the prices of primary factors only. In equation (L-G) Leamer constrains the parameter estimate on intermediate inputs to equal the actual observed price change for intermediate inputs; thus, he accounts for inputs by following equation (3"). Finally, Leamer weights industries by either employment or value-added.

For the various combinations of dependent variable and decade Leamer reports three sets of results. One uses just capital and labor as factors, the second uses capital plus labor disaggregated by Leamer's skills definition, and the third uses capital plus labor disaggregated into nonproduction and production workers (Tables 6 through 8, respectively). The results for wage inequality related to globalization changes in product prices are as follows. For each decade there are four combinations of skill measure (Leamer's or NP vs. P) and pass-through rate (zero or one) to consider. The 1960s results are somewhat mixed: in two of the cases the estimates warrant rising inequality while the other cases warrant falling inequality. The 1970s cases are more clear: in three of the four cases (all except the NP/P measure combined with zero pass-through) the estimates warrant strongly rising inequality. And for the 1980s the results generally split across skill measures. With Leamer's measure and both pass-through assumptions the estimates warrant essentially unchanged or falling inequality, while with the NP/P measure and both pass-through assumptions the estimates warrant rising inequality (although given the reported standard errors 
this rise does not appear to be statistically significant). From the results of these three decades Leamer concludes "that the 1970s was the Stolper-Samuelson decade with product-price changes causing increases in inequality" (p. 31).

The methodology of Leamer closely parallels that of Baldwin and Cain (BC) (1997). ${ }^{4}$ Their empirical analysis consists of a comprehensive set of descriptive facts (Table 1) followed by a more structural approach. Like Leamer, BC also regress a set of cross-industry zero-profit conditions expressed as changes to estimate mandated factor-price changes that can be compared with actual factor-price changes. Unlike Leamer, however, because of concerns that technology data are poorly measured (p. 15), in their econometric analysis BC do not incorporate tfp measures. Their alternative "is to infer from the general equilibrium trade model the biases in the regression coefficients" (p. 15) that are introduced by omitting technological change. Beyond technology, BC also account for influence of national factor supplies as well. Rather than somehow incorporating these influences in the zero-profit regression analysis, $\mathrm{BC}$ evaluate their importance in separate analyses of industry outputs, factor employment ratios, and net exports.

The econometric component of their product-price analysis basically follows equation (2) with the inclusion of an additive error term plus a constant to allow for "possible trends in price variables due to 'outside' forces" (p. 22).

$$
\text { (BC) } P_{j}^{*}=\alpha+\left(\theta_{i j}\right) \beta_{i}+e_{j}
$$

In estimating this equation $\mathrm{BC}$ expand the scope of previous work in several ways. First, like Leamer they cover three decades: 1968 to 1973,1973 to 1979, and 1979 to 1991 . Second, they include all industries in the economy, not just manufacturing industries. Altogether they have 79 two-digit SIC industries used in input-output tables constructed by the Bureau of Economic Analysis (BEA). To ease comparability with previous research their main results are reported two ways: for all industries together and for just manufacturing industries. Third, they obtain

\footnotetext{
${ }^{4}$ The work of Baldwin and Cain--and indeed, all the studies in this paper--is in turn related to Baldwin and Hilton (1984), who model cross-country differences in factor prices as being accounted for by cross-country differences in unit production costs. The key difference between this early study and those surveyed in this paper is Baldwin and Hilton explored crosscountry differences factor by factor whereas the latter explore within-U.S. differences over time in more-skilled and lessskilled wages.
} 
employment from the Current Population Surveys (CPS) which report skills by educational attainment. Educational data are probably a better measure of skills than the commonly used nonproduction-production job classification (which is only meaningful for manufacturing industries). Moreover, these data allow more flexible definitions of skill groups. BC work with three different groupings: 1 to 12 years and 13 or more years; 1 to 11 years and 12 or more years; and 1 to 11 years, 12 years, and 13 or more years. In addition to labor BC also include physical capital. To control for intermediate inputs BC use input-output tables to construct total factor cost shares (i.e., they construct cost shares as given by equation (3')). These I-O tables are available only Census of Manufacturing years, so BC use cost shares from 1967 for their first time period, 1972 for their second period, and 1977 for their final period. In their main analysis BC use annualized changes in domestic product prices (with the endpoints for each period taken as threeyear averages to prevent outlier years from influencing the results). In addition, for manufacturing BC replicate their analysis for the 1980s using export and import prices from 1982 through 1992 (total price changes, not annualized). Finally, BC use both unweighted and weighted least squares with either employment or output weights.

$\mathrm{BC}$ describe aggregate price movements between more-skilled and less-skilled categories in Table 1. For each of the Census of Manufactures years plus the year 1980, BC calculate the domestic price ratio of industries intensively using more-skilled workers to industries intensively using less-skilled workers. They construct this price ratio for two industry samples: all sectors and just manufacturing. Within each sample, each industry is placed in either skill category based on whether its total employment ratio (i.e., ratio of direct employment plus indirect calculated from input-output tables) of workers with 13-plus years of education to workers with 12 or fewer years is above or below the median industry's ratio. From 1967 to 1972 both price ratios fell. From 1972 to 1980 the price ratio for all sectors continued to fall but the manufacturing price ratio rose. Finally, from 1980 to 1992 the price ratio for all sectors rose sharply while the manufacturing price ratio declined. Notice these descriptive price movements within manufacturing generally match 
those found by Leamer: during the 1970s the relative price of unskilled-labor-intensive products fell, but during the 1980 s this relative price did not fall further.

$\mathrm{BC}$ report their main OLS estimation results in Tables 3 and 7; Appendix 1 reports analogous results for the weighted regressions. Again, their overall methodology is first to estimate equation (BC) for each time-period/factor set combination and then to discuss what combinations of changes in trade, technology, and endowments most plausibly explains the observed price patterns and implied mandated factor-price changes indicated by $\beta_{\mathrm{i}}$.

For the period 1968-1973, OLS price regressions for both all industries and just manufacturing industries and all three factor sets mandate a decline in wage inequality. BC argue that this implied decline in the relative price of skilled-labor-intensive products was caused primarily by an expanding relative endowment of skilled labor which in turn expanded the relative output of skilled-labor-intensive products. The weighted regressions yield the same qualitative result.

For the middle period 1973-1979, the OLS price regressions again mandate a decline in wage inequality for both all industries and just manufacturing industries. Analyzing supporting data on outputs, endowments, and net exports, BC conclude that endowment changes were not as strong an influence this period. The three-labor-type regressions for manufacturing only suggest that trade might have helped lower the warranted wage of high-school dropouts relative to high-school graduates. The weighted regressions for this period look qualitatively similar for all industries together but qualitatively different for just manufacturing. The manufacturing weighted estimates tend to indicate a mandated rise, not fall, in wage inequality--particularly when outputs are the weights.

Finally, for the period 1979-1991 BC estimate different mandated-wage patterns across the two industry groups. For all industries together $\mathrm{BC}$ find a mandated rise in wage inequality. For just manufacturing they find a mandated decline in wage inequality (particularly so for the two cases with only two labor types). These manufacturing results are matched by the regressions using the BLS export and import prices. In light of the fact that the manufacturing results suggest that international trade was generating mandated declines in wage inequality rather than the actual rises 
in inequality (p. 40), BC argue that the most-likely explanation for the observed price patterns is a combination of skill-biased technological change and demand shifts toward skilled-labor-intensive products. The results from the weighted price regressions look qualitatively similar, although the manufacturing results are weaker when weighted for the cases with only two labor types.

Krueger (1997) is the only study in this survey to focus on the 1990s, defined in his data as 1989 through 1994. He follows the methodology of both Lawrence and Slaughter and Sachs and Shatz by regressing industry product-price changes on direct factor employment. Specifically, he follows Sachs and Shatz by using the fraction of production workers by industry, measured as the average over the years 1989, 1990, and 1991. He also runs this regression both with and without a dummy for the computer industry.

$$
(\mathrm{K}-1) \mathrm{P}_{\mathrm{j}}^{* 1990 \mathrm{~s}}=\alpha+\beta(\mathrm{PW} /(\mathrm{PW}+\mathrm{NPW}))_{\mathrm{j}}+\beta_{\mathrm{c}}\left(\mathrm{D}_{\text {computers }}\right)+\mathrm{e}_{\mathrm{j}}
$$

In addition, Krueger also follows Leamer and Baldwin and Cain by regressing a set of crossindustry zero-profit conditions expressed as changes to estimate mandated factor-price changes that can then be compared with actual factor-price changes. Unlike Leamer and Baldwin and Cain, Krueger does not attempt in any way to attribute observed product-price changes between trade and non-trade causes. Thus, his mandated-wage specification looks as follows.

$$
(\mathrm{K}-2) \mathrm{P}_{\mathrm{j}}^{*}=\alpha+\left(\theta_{\mathrm{ij}}\right) \beta_{\mathrm{i}}+\mathrm{e}_{\mathrm{j}}
$$

Krueger's data cover the 150 four-digit SIC manufacturing industries which have at least 75 percent of their output going to final consumer demand--i.e., "finished processor" industries. The product prices are the domestic producer prices like those used in many of the earlier studies. In his cost-share matrix Krueger includes more-skilled labor, less-skilled labor, capital, and materials. Thus, like Leamer he accounts for intermediate inputs as suggested by equation (3"). For equation (K-1) Krueger uses the nonproduction-production classification; for robustness he also uses average worker educational attainment by industry merged in from the CPS. To calculate industry cost shares of less-skilled labor in equation (K-2) Krueger multiplies industry total employment by the average annual earnings of a high-school dropout and then divides this product by industry value of shipments. More-skilled cost shares are calculated as total payroll less this 
product all divided by industry value of shipments. All regressions are estimated with weighted least squares using 1988 value of shipments as weights.

Krueger's results from equation (K-1) are reported in Figures 1 and 2, Table 4 (columns 1 and 2), and Table 5 (column 2). His main finding is that $\beta$ is estimated to be statistically significantly less than zero with virtually the same point estimate either with or without the computer dummy variable. That is, the data indicate a positive correlation between product-price increases and skill intensity. Measuring skill intensity by educational attainment yields the same result.

The result from equation (K-2) is reported in Table 5 (column 1). The main finding here is an estimated mandated rise in wage inequality: the difference between the estimated $\beta_{i}$ 's for skilled and unskilled labor is 0.52 and is statistically significant at the .0001 level. In an unreported robustness check Krueger obtains qualitatively similar results from OLS and median regressions, although the estimated rise in warranted inequality is smaller (p. 17). Thus Krueger draws the same conclusion from the results of both equation (K-1) and (K-2): "fairly robust evidence that price growth was relatively lower in less-skill intensive industries between 1989 and 1995 ... The magnitude of the price changes is roughly compatible with observed wage changes for skilled and unskilled workers" (pp. 19-20).

Feenstra and Hanson (FH) (1997) also use the mandated-wage framework used by Leamer, Baldwin and Cain, and Krueger. However, FH differ from these earlier studies in an important way. They do not consider product-price changes to contain any direct evidence of the role of international trade on factor prices. Rather, building on their earlier model of outsourcing (FH (1995)) they argue that outsourcing manifests itself in industry-level data as tfp growth. Because outsourcing changes the mix of activities done within industries, "this will shift the entire production function for activities done at home, and therefore show up as a change in total factor productivity" (p. 13). 5

\footnotetext{
${ }^{5}$ With regard to mandated-wage regressions, FH also point out that mandated-wage regressions like equation (2') fit the data perfectly (i.e., have an R-squared equal to one) if one includes as a regressor differences between industry-specific and economy-wide changes in factor prices.
} 
Their empirical approach thus involves two steps. First, they decompose observed tfp into a component attributable to outsourcing and a separate component attributable to investment in hightechnology equipment. They do this by regressing observed industry tfp growth on measures of outsourcing and computer investment and then using the parameter estimates to do the decomposition. Second, "By using each one of these components in place of total TFP ... we will be able to estimate the change in factor prices consistent with that component alone" (p. 13). The two-step approach is similar to that of Leamer, who first decomposes observed product-price changes into a technology component and a globalization component and then regresses each component on factor-cost shares to estimate mandated factor-price changes attributable to each component. Thus, the mandated-wage regression of FH looks like this.

$$
\text { (FH) "Outsourcing" } \mathrm{TFP}_{\mathrm{j}}{ }^{*}=\left(\theta_{\mathrm{ij}}\right) \beta_{\mathrm{i}}+\mathrm{e}_{\mathrm{j}}
$$

The dependent variable is the estimate of tfp attributable to some measure of outsourcing; because this regressand is estimated FH adjust their standard errors on $\beta_{\mathrm{i}}$. There are two important comments to make about this dependent variable. First, FH use two different measures of outsourcing and thus have two different sets of outsourcing-related regressands. One "narrow" measure tracks imports of intermediate inputs only from the same two-digit industry as the good being produced. A second "broad" measure tracks all imported intermediate inputs regardless of industry. In their analysis FH actually use the narrow measure and then the difference between the broad and narrow measures. Second, for each of the two measures of outsourcing FH use two different constructions of ("Outsourcing" $\mathrm{TFP}_{\mathrm{j}}{ }^{*}$ ). The first assumes zero pass-through from these outsourcing-induced tfp improvements to product prices. The second allows some pass through both to lower product prices and to industry-specific wage differences from economy-wide average wages. Unlike Leamer who assumes a single pass-through rate common to all industries, FH estimate the pass-through rate by regressing observed product-price changes less industry wage differences against actual tfp, outsourcing, and computer investment. Their point-estimate passthrough rates are 1.725 for the period 1972-1979 and 1.040 for the period 1979-1990. Thus, for each time period $\mathrm{FH}$ actually estimate four versions of the (FH) equation: two different measures 
of outsourcing and two different assumptions about whether or not outsourcing feeds through to product-price changes.

For all regressions FH use 446 of the 450 four-digit SIC manufacturing industries. Three industries are excluded because of inadequate data on materials, and computers (SIC 3573) is also excluded because it "was an extreme outlier and had to be excluded to obtain any sensible results ... When this industry is pooled with the others ... it results in unrealistically large estimates for predicted wage changes" (pp. 21-22). The nonproduction-production classification is used to separate more-skilled from less-skilled workers, and capital is included as a third primary factor. As stated above, FH use two different time periods. Also, FH test the robustness of their results by using alternative measures of computerization. All regressions use weighted least squares with average value of shipments during the relevant period as weights.

The key results for the zero-pass-through case are reported in Tables 5 and 6; the analogous results for the case allowing pass-through are in Tables 7 and 8. In the zero-pass-through case, in both time periods across all different computerization measures both narrow and broad measures of outsourcing yield mandated-wage estimates of rising wage inequality. Indeed, for the 1980s either measure yields a mandated rise in inequality greater than the actual rise. However, most of the parameter estimates are sufficiently imprecise that the mandated rise in inequality is not statistically significantly different from zero. In the case with pass through results are less uniform. During the 1970s both measures of outsourcing lead to parameter estimates of a mandated decline in inequality--although again, all these none of these parameter estimates differs significantly from zero. During the 1980s the narrow outsourcing measure mandates a rise in inequality that is statistically significant across all computer measures. In contrast, the broad outsourcing measure mandates a fall in inequality but not significantly so for two of the three computerization measures.

Overall, FH estimate that the narrow measure of outsourcing mandated rising inequality across all specifications. However, the results for narrow outsourcing during the 1970s and for broad outsourcing in both decades are more sensitive to the pass-through assumption. 
Finally, Harrigan and Balaban (HB) (1997) analyze product-price changes using a methodology different from the mandated-wage regressions. Their goal is to model economy-wide wages as determined jointly by technology, endowments, and product prices--which can be influenced, among other things, by international trade. Thus like Leamer and Baldwin and Cain, HB consider wage determinants other than international trade. HB start with a national revenue function with the standard properties implied by perfect competition, profit maximization, and nonjointness of production. HB then assume that this revenue function can be written as a general translog function with parameter restrictions implied by the standard properties. From this functional form a set of equations can be derived which relate each factor's share in total national income to technology, factor supplies, and product prices. With appropriate data these cost-share equations can be estimated, and the parameter estimates linking factor cost shares with technology, endowments, and product prices can be combined with observed changes in these regressors to decompose actual wage changes into components due to technology, endowments, and prices.

HB apply this model to U.S. data from 1963 through 1991 by decomposing the economy into four primary factors and four products. The primary factors are high-school dropouts, highschool graduates plus some college, college graduates, and physical capital. There are two tradable and two nontradable industries, one each intensive in more-skilled labor and the other intensive in less-skilled labor. Total industry factor intensities are determined using both direct and indirect factor employments from 1977 input-output tables. Thus like Baldwin and Cain, HB focus on the entire U.S. economy and not just tradables.

HB consider U.S. product prices to be endogenous and thus require instruments for consistent estimation. For domestic prices their instrument set includes a set of domestic variables such as factor supplies, tfp, and government demand. For tradables prices HB use a set of international variables meant to capture the effect of developments abroad communicated to the United States through changes in our product prices. More specifically, they construct variables aimed at measuring "the presence of each country's labor supply in the international market" (p. 9). To do this, for each year HB separate all countries into four income quartiles and then sum across all 
countries in each quartile the product of each country's labor force multiplied by its ratio of gross trade to GDP. Thus, HB are the first researchers to try to model the effect on U.S. prices of "international trade" in terms of foreign changes in productive capacity communicated to the United States through changes in our product prices.

The main results from their wage decomposition are reported in Table 5. HB find that the most important relative-price change contributing to rising wage inequality was the large increase in the price of nontraded skill-intensive products relative to tradables and to the other nontraded sector. The effects of changes in tradables relative prices are less clear: parameter estimates for these variables are relatively imprecise. This suggests that the international instruments might be weak.

\section{Synthesis of Existing Findings and Methodological Progress}

Having surveyed each of the nine product-price studies individually, I now try to synthesize their similarities and differences. I do this in three steps. First, I discuss how research has refined a set empirical strategies for applying the SS theorem to the data. Second, I comment on some important methodological issues regarding the robustness of results. "The facts" about product prices and their warranted wage changes are relatively sensitive to the selection and weighting of industries sampled and to the decade considered. In contrast, "the facts" are relatively insensitive to the extent of data aggregation and the measurement of skills. Third, in light of these methodological issues I summarize what "the facts" seem to be about product-price changes and their mandated wage changes.

\section{A Methodological Progression}

Here is a summary of the various empirical methodologies surveyed in the previous section.

Bhagwati (1991): Discussion of U.S. terms of trade

Lawrence and Slaughter (1993): Regression analysis

$$
\text { (LS) } \mathrm{P}_{\mathrm{j}}{ }^{* 1980 \mathrm{~s}}=\alpha+\beta(\mathrm{NPW} / \mathrm{PW})_{\mathrm{j}}{ }^{1980}+\mathrm{e}_{\mathrm{j}}
$$

Sachs and Shatz (1994): Regression analysis

(SS) $\mathrm{P}_{\mathrm{j}}{ }^{* 1980 \mathrm{~s}}=\alpha+\beta(\mathrm{PW} /(\mathrm{PW}+\mathrm{NPW}))_{\mathrm{j}}{ }^{1980}+\beta_{\mathrm{c}}\left(\mathrm{D}_{\text {computers }}\right)+\mathrm{e}_{\mathrm{j}}$

Feenstra and Hanson (1995): Descriptive comparison of domestic and import prices 
Leamer (1996): Discussion of industry relative prices plus regression analysis

$(\mathrm{L}-\mathrm{T})\left[(1-\lambda) \times \mathrm{TFP}_{\mathrm{j}}{ }^{*}\right]=\left(\theta_{\mathrm{ij}}\right) \beta_{\mathrm{it}}+\mathrm{e}_{\mathrm{j}}$

$(\mathrm{L}-\mathrm{G})\left[\mathrm{P}_{\mathrm{j}}^{*}+\left(\lambda \times \mathrm{TFP}_{\mathrm{j}}{ }^{*}\right)\right]=\left(\theta_{\mathrm{ij}}\right) \beta_{\mathrm{ig}}+\mathrm{e}_{\mathrm{j}}$

Baldwin \& Cain (1997): Discussion of industry relative prices plus regression analysis

(BC) $\mathrm{P}_{\mathrm{j}}^{*}=\alpha+\left(\theta_{\mathrm{ij}}\right) \beta_{\mathrm{i}}+\mathrm{e}_{\mathrm{j}}$

Krueger (1997): Regression analysis

$(\mathrm{K}-1) \mathrm{P}_{\mathrm{j}}{ }^{* 1990 \mathrm{~s}}=\alpha+\beta(\mathrm{PW} /(\mathrm{PW}+\mathrm{NPW}))_{\mathrm{j}}+\beta_{\mathrm{c}}\left(\mathrm{D}_{\text {computers }}\right)+\mathrm{e}_{\mathrm{j}}$

$(\mathrm{K}-2) \mathrm{P}_{\mathrm{j}}^{*}=\alpha+\left(\theta_{\mathrm{ij}}\right) \beta_{\mathrm{i}}+\mathrm{e}_{\mathrm{j}}$

Feenstra and Hanson (1997): Regression analysis

$(\mathrm{FH})$ "Outsourcing" $\mathrm{TFP}_{\mathrm{j}}{ }^{*}=\left(\theta_{\mathrm{ij}}\right) \beta_{\mathrm{i}}+\mathrm{e}_{\mathrm{j}}$

Harrigan and Balaban (1997): Regression analysis of cost-share equations from translog representation of U.S. revenue function

How do these different approaches relate to each other? By listing them chronologically, I think one can identify a progressive refinement of how to apply the SS theorem in the data.

First, the studies of Bhagwati, LS, and SS I call "consistency checks." That is, these studies analyze whether observed product-price changes were consistent with rising wage inequality in the sense that the relative price of skilled-labor-intensive products rose relative to those of unskilledlabor-intensive products. Bhagwati simply assumes that exports (imports) employ more-skilled (less-skilled) labor relatively intensively. LS, and SSh following LS, refine this assumption by using disaggregated data to identify the pattern of relative factor usage.

These first studies have some important limitations in terms of the distance between SS theory and the empirical analysis and in terms of appropriately accounting for data complexities. One important limitation is that a consistency check on product prices cannot make the important link to factor prices. It cannot answer the important question of how much product-price changes might have contributed to actual factor-price changes. Another major limitation is that these regressions of product-price changes on factor-employment levels is not a tight implication of the SS theorem's zero-profit logic as summarized in equations (1) and (2). Equation (1) relates price levels to factoremployment levels (i.e., to the A matrix) while equation (2) relates price changes to factor cost shares (i.e., to the $\theta$ matrix). Regressing price changes on employment levels seems to capture the 
broad intuition of the SS theorem, but it uncomfortably mixes the levels and changes versions of the zero-profit conditions central to the SS theorem.

There are some data limitations as well. One is that these studies assume that the United States does not affect world prices: changes in domestic (or export or import) prices reflect changes in world prices triggered abroad that are communicated to the price-taking U.S. economy. Another limitation is that these studies ignore capital and any other primary factors of production. Given this, their results are best interpreted as a test of the General, Restrictive, or Essential Versions of the SS theorem under the maintained assumption that other primary factors don't matter. A third limitation is they measure only direct factor intensities: they do not account for factor usage embodied in intermediate inputs.

The later studies improve upon the "consistency check" methodology in several ways. Most importantly, they have less distance between SS theory and their empirical analysis. The mandated-wage regressions of Leamer, BC, Krueger, and FH come closer than the consistency checks to testing the Correlation Version of the SS theorem that, as discussed in Section 2, is probably the version most applicable to the issue of rising wage inequality. And these regressions follow directly from the zero-profit conditions expressed in terms of changes in equation (2), rather than mixing changes with levels. Product-price changes (or some other trade-related exogenous force such as outsourcing for $\mathrm{FH}$ ) are the dependent variable, factor cost shares are the independent variable, and factor-price changes are the parameter estimates. These estimates have a clear interpretation in light of equation (2) as the "best guess" factor-prices changes mandated by changes in the dependent variable to maintain zero-profits in all producing sectors. In terms of the SS Correlation Version in equation (4), these mandated "best guesses" estimate the correlation between changes in the dependent variable and changes in the cost-share weighted factor prices. Comparing actual with mandated factor-price changes indicates how much of the actualfactor-price changes can be accounted for by the dependent variable. The ability to do this accounting within the mandated-wage framework solves one of the major limitations of the consistency-check framework. (This is not to say that descriptive consistency checks are abandoned altogether-- 
Leamer and BC complement their regressions with stylized facts, and Krueger also estimates LSstyle regressions). And as Leamer and FH (1997) demonstrate, this mandated-wage framework can be used not just for product-price changes but for technology changes as well. ${ }^{6}$

The mandated-wage studies also have the advantage of better treatment of some data complexities. Several of them try to relax the assumption of a small price-taking U.S. economy, as will be discussed below in greater detail. In addition, these studies also account forintermediate inputs as well as primary factors.

Mandated-wage regressions might appear odd because the exogenous variable is the regressand rather than the regressor while the dependent variable of interest (factor-price changes) is estimated rather than the regressand. The most important reason a "standard" regression cannot be used is the dimensionality of the data prevents inversion of the $\theta$ matrix. For example, the NBER Productivity Data Base used by LS, Leamer, and FH contain 450 four-digit SIC manufacturing industries but only three primary factors plus two intermediate inputs. With more products than factors, in equation (2) the $\theta$ matrix is not square and thus cannot be inverted to obtain a set of equations equating wage changes with product-price changes multiplied by an inverted $\theta$ matrix.

This lack of invertibility suggests that the warranted-wage regressions can be interpreted as an accounting exercise rather than one identifying causation in the way regressions are usually presumed to. Warranted-wage regressions estimate what changes in factor prices are mandated from the observed changes in technology and/or product prices. With these mandated changes one can determine what share of actual wage changes is accounted for by the driving exogenous change. Note that because the exogenous change enters the regression as the dependent variable, the mandated-wage methodology cannot analyze two or more exogenous forces in the same regression--it can process only one exogenous force at a time.

\footnotetext{
${ }^{6}$ Building on these examples, Haskel and Slaughter (1998) use the mandated-wage framework to document that the sector bias of skill-biased technological change appears to account for much of the fall and subsequent rise in wage inequality over the 1970s and 1980s in both the United Kingdom and United States.
} 
Overall, the product-price methodology has advanced from consistency checks to warrantedwage regressions. I argue that this progression has moved empirical work closer to the motivating SS theory in a number of important ways.

\section{How Robust Are "The Facts"? Methodological Issues}

The variety of empirical methods used in this research area raises the issue of how robust results are to various methodological choices. In this section I discuss how sensitive results are to four different robustness issues: the selection and weighting of industries sampled; the decade considered; the extent of data aggregation; and the measurement of skills.

\section{Robustness to Industry Selection and Weighting}

The SS theorem's zero-profit conditions apply to all domestic industries currently producing positive output. In the matrix equations (1) and (2) there are $\mathrm{N}$ rows corresponding to all $\mathrm{N}$ industries currently being produced. Any domestic industry not currently producing is assumed to have average costs exceeding industry's price; thus that industry has no zero-profit equality. This suggests that empirical work on the SS theorem requires data on all operating domestic industries.

This raises two separate issues. One is whether to limit the sample to just all operating domestic industries that are tradable. As discussed in Section 2, four of the versions of the SS theorem do not explicitly involve international trade. The link between product prices and factor prices holds even in autarky. Given this, focusing on just tradable industries seems appropriate when trying to understand product-price changes attributable to international trade. ${ }^{7}$ The other issue is conditional on a selected sample, are all available industries included in the data analysis. Theory suggests that all data should be included. Missing industries introduces the risk of not being representative of the appropriate full sample.

How robust are empirical results to sample selection? First, results definitely depend on whether all sectors or just tradables are analyzed. Looking at all sectors together, $\mathrm{BC}$ and $\mathrm{HB}$ find an increase in the price of skill-intensive nontradables during the 1980s. In light of SS versions

\footnotetext{
7 Another reason to focus on just tradable industries is that if external competitiveness conditions are sufficient to determine an economy's factor prices, then that economy's nontraded product prices are determined automatically by these factor prices and the state of nontraded production technology. In this case, with fixed nontraded technology nontraded product prices mechanically follow national factor prices.
} 
that do not directly involve international trade, this suggests that one cause of rising inequality was rising relative prices for skill-intensive nontraded products. For the subset of just tradable manufactures, LS, Leamer, and BC all find no strong trend in relative prices during the 1980s. This finding suggests that trade did not contribute to rising inequality. Clearly, in comparing studies one must be careful to identify differences driven by sample selection of tradables versus nontradables.

Conditional on selecting the overall set of industries to analyze, empirical results also depend on whether data on all available industries is included. In some cases results have been somewhat robust to sample selection. For example, both LS and BC use import and export prices for manufacturing industries despite the fact that these data do not exist for every single manufacturing industry. Import prices exist for only 18 of 20 two-digit SIC industries and only about 50 of 143 three-digit SIC industries. Despite this, both LS and BC find no strong trend in relative prices during the 1980s for these smaller samples, matching the results of Leamer and BC using the full set of 450 four-digit manufacturing industries.

But in other cases the issue of inadequate sample selection appears to be very crucial. For example, Krueger's analysis of the 1990s uses only 150 of the 450 four-digit SIC manufacturing industries. He acknowledges that his sample of finished-processor industries is incomplete and comments that in "a later draft of this paper, I hope to obtain data for non-finished goods industries" (fn. 8, p. 8). It seems reasonable to wonder whether his analysis is representative of manufacturing overall during this period.

Because the NBER Productivity Data Base covering all four-digit manufacturing industries now extends through 1994, this can be checked. I have used these data to replicate Krueger's findings for the sample of finished-processor industries and then to see what results obtain when the sample is expanded to include all industries. Because I do not have all of Krueger's data to replicate his construction of factor cost shares I follow Leamer's approach for constructing cost shares for nonproduction labor, production labor, capital, energy, and materials. These alternative measures seem reasonable in that they replicate Krueger's results. The cost-share regressors are 
for 1989 and the dependent variable is the annualized rate of change in industry price. For all sets of industries I regress product-price changes on the cost shares to estimate the mandated factorprice changes.

Table 1 reports the results. The first three rows replicate Krueger's finding that for the sample of finished-processor industries the mandated wage increase for nonproduction labor exceeds that for production labor. The second three rows expand the sample to all manufacturing industries. Qualitatively, the parameter estimates between the two labor types have flipped. Now production labor has a larger mandated wage increase than nonproduction labor--this implies a mandated decline, not increase, in wage inequality. The final three rows show that the non-finishedprocessor industries are driving the different results for overall manufacturing. For this sample of industries the annualized mandated decline in inequality is larger than that of manufacturing overall. Notice that the results are robust to alternative weighting schemes for industries. ${ }^{8}$

On balance, then, it seems that Krueger's results for the 1990s are particular to his sample of industries. Table 1 suggests that for the full sample of all manufacturing industries the productprice changes during the early 1990s were not mandating increased wage inequality.

The issue of sample selection can even hinge on the presence or absence of a single industry. For example, as mentioned earlier FH (1997) omit the computer industry (SIC revision 2 industry \#3573) from their sample because they report that results with computers are not plausible. SSh do not literally drop computers from the sample, but the effectively do so with a dummy variable for this industry. As discussed earlier, SSh treat computers differently because of concerns that reported computer prices do not adequately reflect the extent of this industry's quality upgrading.

How much do computers really matter for the SSh results? They do not report results for the (SSh) equation excluding the computer dummy, but this can easily be done using the NBER's Productivity Data Base. SSh use three-digit data, I use the four-digit data assuming that more-

\footnotetext{
${ }^{8}$ Results are also robust to using 1988 or 1990 cost shares and to using the total-period price change. A similar difference between the full manufacturing sample and just finished-processor industries shows up for regressions of price changes on the share of production workers in total employment.
} 
disaggregated data are better. SSh report unweighted regressions; for robustness I also use value of shipments and employment to weight industries.

Table 2 reports the results. The key message is that "computers matter." Without a computerindustry dummy no strong relationship appears between product-price changes and the share of production workers in total industry employment. But as was reported for SSh earlier, with a computer-industry dummy effectively removing this industry a strong negative relationship appears among the non-computer industries.

Given that computers (and perhaps other single industries?) can play such an important role, when can industries be excluded from analysis? Lack of data seems to be one justifiable reason. Examples include LS and $\mathrm{BC}$ using all tradables price data that exist and $\mathrm{FH}$ excluding three industries which did not have materials prices. LS explicitly state their assumption that their smaller samples are representative of overall manufacturing (fn. 55, p. 195 and fn. 63, p. 202).

The issue of selectively excluding data which do exist seems to be a trickier issue. FH invoke the reasonable criterion of excluding data that drive nonsensical results. SSh invoke the criterion of bad data quality. They do not elaborate this point, however, either in terms of why computerprice data are so bad in absolute terms or, more importantly, relative to other industries. Presumably other industries also had quality improvements which need to be accounted for in constructing "true" price changes.

At the very least, when possible the direction of bias introduced by "bad" data should be considered before excluding data. For example, SSh claim that reported computer prices do not adequately control for quality improvements. Stated another way, they argue that the reported price decline for computers, in absolute value, understates the true quality-adjusted price decline for computers. This suggests that the reported price decline in computers is biased upwards towards zero. The solution that SS use of dummying out the computer industry actually reinforces this bias rather than mitigating it. Rather than using information about the direction of bias, the dummy variable effectively sets the price change for the computers to zero when estimating the cross-industry relationship between price changes and relative employment. To control for the bias 
introduced by computers, therefore, the results without the computer dummy are arguably better than the results with the computer dummy.

Related to the issue of industry selection is the issue of industry weighting. The logic of the SS theorem suggests that empirically all industries should be weighted equally. The link from product prices to factor prices relies on the existence of industries, not their sizes. Thanks to the assumption of perfect interindustry factor mobility, as long as an industry has positive output its product price can and does affect factor prices in every industry. That is, as long as an industry has some positive output it accounts for one of the rows in matrix equations (1) and (2) regardless of how large the industry is. A product-price change in even the smallest industry is qualitatively just as important as a product price in the largest industry. This suggests that any data analysis should weight all industries equally.

Given the theoretical preference for equally weighted industries, weighting data differently probably requires some overriding empirical justification. For example, as BC suggest (fn. 29, p. 22) one might weight larger industries more heavily if smaller industries had poorer quality data. Another reason to weight might be that many smaller sectors are residual categories of a wide range of products.

Does weighting industries differently matter? In finite samples ordinary and weighted least squares yield different parameter estimates. On balance, the answer appears to be "maybe." Instances where weighting does not change the qualitative results include Krueger's work on the 1990s (and the extensions thereof in Table 1). BC offer the most insight on this issue with their very thorough reporting of both unweighted and weighted results using both employment and output as weights. For the 1960s and 1980s results look very similar across the weighted and unweighted specifications. But for manufacturing industries during the 1970s weighting seems to matter much more. Their unweighted results suggest a mandated fall in inequality but their weighted results--particularly with output weights--suggest a mandated rise in inequality. This difference seems particularly important when compared with Leamer's conclusion that the 1970s was the "Stolper-Samuelson decade" with a large rise in mandated inequality. Leamer's reports 
this finding only for weighted specifications, not unweighted ones. Employment and value-added weights give similar results, but that "unweighted regressions are entirely different" (fn. 5, p. 29).

\section{Robustness to Different Decades}

Different decades appear to have different product-price trends. Assuming for the moment that the evidence presented in the previous studies is correct, on balance it appears that the U.S. prices of less-skilled-labor-intensive products relative to more-skilled-labor-intensive products held relatively constant during the 1960s and 1980s but declined during the 1970s and 1990s. Thus it is important not to generalize about "the" pattern in U.S. product prices without specifying the particular time period. For example, Krueger concludes that his evidence of declining relative prices during the 1990s "is consistent with Sachs and Shatz (1994), but inconsistent with Lawrence and Slaughter (1993)" (p. 19). Because SS and LS analyze the 1980s, not the 1990s, it is not clear that there should be any necessary relationship among results across different decades.

Importantly, the results for each given decade appear to be fairly robust to the endpoints chosen. For example, LS, Leamer, and BC all find no strong trend in manufacturing relative prices during the 1980 s even though each study dates the decade slightly differently. ${ }^{9}$

\section{Robustness to Data Aggregation}

The SS theory is largely silent on this point. In theory different industries are distinguished by their different relative employment of factors as dictated by their different production technologies. Empirically, it is generally assumed that more-disaggregated data is better.

The results appear to be quite robust to data aggregation. Many studies of the manufacturing sector use four-digit SIC industries (Leamer, Krueger, FH). Studies using three-digit data (LS, SS, BC) and/or two-digit data (LS, BC) obtain qualitatively similar results to the moredisaggregated studies. For example, the finding of constant relative manufacturing prices during the 1980s is obtained at the four-digit level (Leamer), the three-digit level (LS and BC) and the two-digit level (LS and BC).

\footnotetext{
${ }^{9}$ Obviously there were other differences among these three studies, so the role of timing alone cannot be determined with certainty. Unfortunately, none of the studies reports a robustness check of its own methodology to timing the decades.
} 


\section{Robustness to Measurement of Skills}

Trade theory is largely silent on this point of how to measure skills. It is generally accepted that the nonproduction-production classification for manufacturing workers suffers more misclassification of skills than a categorization based on education. However, this is claim is a statement about noisiness of data, not necessarily bias.

In fact, the nonproduction-production classification does not appear to be a biased measure of skills. Studies using this measure tend to obtain similar results to other measures such as educational attainment. Again, for the 1980s the conclusion of relatively stable relative product prices and thus little mandated change in wage inequality is obtained from studies using the nonproduction-production classification (LS, Leamer for the case of zero pass-through), using educational attainment to identify two labor groups (BC with two different cutoff points between the two groups), and using skills inferred form actual wages paid (Leamer). Similarly, for the 1990s for the sample of finished-processor industries Krueger obtains the same result for equation (K-1) using both the nonproduction-production classification and average years of education. The results for equation (K-2) are qualitatively the same for the nonproduction-productionclassification (reported in Table 1 of this paper) as for Krueger's skill measure using minimum wages combined with total wage bills.

\section{A Summary of "The Facts" Regarding Product-Prices and Mandated Wages}

In light of the previous discussion about methodological robustness, here is a summary of "the facts" regarding product-price changes and the mandated wage changes. To organize the summary I use decades. HB do not break their analysis by time period, so I report one of their important findings in the 1980s.

The 1960s have been analyzed by BC and Leamer. The consensus finding seems to be a slight decline in the relative price of skill-intensive industries both within manufacturing and all sectors overall. These price changes suggest a mandated decline in wage inequality during this period.

The 1970s have been analyzed by BC, Leamer, and FH (1997). The consensus finding between $\mathrm{BC}$ and Leamer seems to be a moderate to substantial decline in the relative price of 
unskill-intensive industries both within manufacturing and all sectors overall. These price changes suggest a mandated rise in wage inequality during this period. In contrast, $\mathrm{FH}$ find that outsourcing's effect on observed tfp mandated declining wage inequality during this period.

The 1980s have been analyzed by Bhagwati, LS, SS, FH (1995), Leamer, BC, FH (1997), and HB. The consistency checks of Bhagwati and LS and the descriptive facts of Leamer and BC all find no clear pattern of price changes across tradable industries during this period. The consistency check of SS does find evidence of a relative-price decline for unskill-intensive industries, but only after dummying out the computer industry. The mandated-wage regressions of Leamer and $\mathrm{BC}$ on manufacturing industries both find no clear pattern of mandated changes in wage inequality during this period. The structural estimates of HB corroborate this. FH (1995) find that the greater rise in domestic prices relative to import prices is consistent with their model of outsourcing, and FH (1997) find that changes in their narrow measure of outsourcing working through observed tfp (and also through product prices for some specifications) led to mandated rises in wage inequality. Both $\mathrm{BC}$ and $\mathrm{HB}$ find a rise in the relative price of skill-intensive nontradable industries during this period which mandated a rise in wage inequality.

The 1990s have been analyzed by Krueger. Based on a sample of one-third of manufacturing industries, both his consistency check and his mandated-wage regressions find a mandated rise in wage inequality from 1989 through 1994. However, evidence I presented in Table 1 for all manufacturing suggests, if anything, a mandated decline in wage inequality.

\section{Limitations of Current Research and Directions for Future Research}

Despite the methodological progress that has been made, research to date still has fundamental limitations regarding the key question of how much international trade has contributed to rising wage inequality. In this last section I highlight three important limitations: the need for a clearer understanding of how product-price changes are related to exogenous forces attributable to international trade; the need to explore how slowly the Heckscher-Ohlin clock ticks; and the need to complement product-price data with other data that might overcome potential limits of the productprice data. 


\section{Decomposing Product-Price Changes}

Most importantly, more work needs to link exogenous forces attributable to international trade to actual product-price changes. Stated alternatively, the literature to date has made substantial progress understanding how to relate a given change in relative product prices to changes in relative factor prices. But it has made relatively less progress understanding whether these product-price changes have anything to do with international trade.

This criticism of product-price studies is not new. Indeed, in a comprehensive survey of rising inequality Freeman $(1995$, p. 29) made the very same point three years ago: "Perhaps the biggest problem with these studies is that they ignore potential determinants of changes in sectoral prices and potential reasons for the proportion of unskilled workers in a sector to be correlated with changes in prices, save for trade." But what's important is that three years later, despite some progress the criticism still applies.

The studies of Bhagwati, LS, SS, and Krueger assume (explicitly or implicitly) that U.S. product prices are determined in the rest of the world without any influence from U.S. variables. This assumption is a reasonable first-pass at the data but it is almost certainly not correct. The other studies in this survey move away from this assumption in various ways. Leamer decomposes observed product-price changes into two components: technological progress, and "globalization" price changes. However, he does not attribute these "globalization" price changes to anything more specific such as trade barriers or foreign developments communicated through the U.S. terms of trade. BC consider three different forces acting on product prices: international trade, technology, and endowments. Like Leamer, though, they do not specify anything more specific regarding what trade's force consists of. FH (1997) use regression analysis to explain observed tfp changes with outsourcing and computerization. In estimating the mandated wage changes driven by each of these tfp drivers they allow an endogenous response of product prices. Finally, instead of using direct measures of domestic product prices in tradable industries HB instrument for these prices using data on foreign labor endowments and trade quantities. 
These latter studies which attempt to decompose product-price changes among various causes are an improvement on the earlier first-pass studies. Nevertheless, it seems that much more work is needed here. As discussed in Section 2, in theory the question of "how does international trade cause product-price changes?" can be refined with reference to at least four different trade-related forces that are plausibly exogenous to domestic firms at a point in time: U.S. political trade barriers; foreign trade barriers; worldwide natural trade barriers; and developments abroad in parameters such as tastes, technology, and endowments that are communicated to the United States via the international prices constituting our terms of trade. None of the nine studies in this survey uses data on political or natural trade barriers. And only HB uses data on foreign parameters to help explain U.S. domestic product prices.

Granted, decomposing product-price changes requires more data. But as HB demonstrate, at least some progress could be made here. For example, perhaps sensible use could be made of netexport patterns among countries. Ideally there would be sufficient data on all forces affecting product prices--both trade-related and otherwise--to account for price movements similar to how FH (1997) account for tfp movements in terms of outsourcing and computerization.

Having a clearer decomposition of product-price changes could contribute greatly to understanding both of what has caused past price changes and what might cause future price changes. To illustrate this consider the relative prices of textiles and apparel, two of the most unskilled-labor-intensive industries in U.S. manufacturing. In his descriptive facts, Leamer documents that the relative producer prices of these unskilled-labor-intensive sectors declined dramatically during the 1970s but stabilized during the 1980s. There are at least two alternative trade-related explanations for why the decline halted. One is that these sectors enjoyed more protection in the 1980s thanks to a more-binding Multi-Fiber Agreement (MFA). Another is that the price declines of the 1970s forced domestic producers to eliminate the very unskilled-laborintensive sectors within textiles and apparel and to focus on the relatively skilled-labor-intensive sectors. With the rest of the world continuing to produce the very unskilled-labor-intensive sectors, this second story implies the United States moved to a different cone of diversification. 
These two stories carry very different implications for future U.S. product prices and thus factor prices. In the first case, the 1980s price stabilization is temporary lull that will disappear as the MFA is phased out and/or as countries like China with comparative advantages in unskilledlabor-intensive products continue to integrate into the world economy. Thus, this first case foreshadows further trade-induced rises in U.S. inequality. The second case, however, looks much rosier. It suggests that the U.S. has already incurred the pain of losing some of its unskilled-labor-intensive industries. As countries like China continue to expand production and thus lower the relative prices of these products no downward pressure is put on U.S. unskilled wages. Instead all U.S. factors enjoy a consumption real-wage increase. Clearly, a better understanding of the relative causes of U.S. domestic price changes would help distinguish which of these very different futures seems more likely.

\section{How Slowly Does the Heckscher-Ohlin Clock Tick?}

The Heckscher-Ohlin (HO) framework of the SS theorem assumes that within a country each factor of production can move costlessly from one industry to another. In this sense, HO theory is a long-run theory: it focuses on how the economy operates once factors have had sufficient time to locate in whatever industries they choose. In contrast, the Ricardo-Viner (RV) framework assumes that within a country some factors cannot move across industries--perhaps because these factors incur prohibitively high moving costs. In this sense, RV theory is a short-run theory: it focuses on how the economy operates when some factors cannot relocate from their current industry.

When a shock hits the economy (e.g., a change in international product prices), most trade economists presume that RV theory describes how the economy reacts in the short run while $\mathrm{HO}$ theory describes how the economy reacts in the long run. It is well known that the reactions usually look very different depending on the time horizon. For example, after a price rise in some industry a country's relatively scarce factor can enjoy short-run wage increases when employed that industry--but in the long run these increases completely reverse and the factor suffers wage declines. 
Despite these clean theoretical results, there is very little empirical evidence on what this transition from short run to long run looks like in reality. This lack of evidence poses a potentially very serious problem for almost all the empirical work to date on the effect of international trade on wage inequality. Every study surveyed in this paper tries to explain inequality changes with contemporaneous product-price changes. Thus, for example, researchers exploring rising inequality during the 1980s analyze trends in product prices during the 1980s. The implicit assumption in all these studies is that the U.S. economy is "sufficiently HO in nature" that price shocks over some time period affect the economy as predicted by HO theory in that same period.

But what if that assumption is incorrect? What if the U.S. economy has sufficiently important short-run "frictions"--imperfect information, high costs of reallocating capital across sectors, people reluctant to relocate geographically, etc.--that price shocks over some time period do not generate HO factor-price effects in that same period? A lot of research indicates that these frictions can matter for several years. For example, Blanchard and Katz (1992) find that in states hit by aggregate-demand drops people can take between five and ten years before deciding to move away to recover economically. The more important these frictions are, for any given shock the longer the economy adjusts in an SF manner before switching over to an HO manner.

If price shocks do not generate $\mathrm{HO}$ wage effects over the same time horizon then the basic methodology of linking prices and wages contemporaneously is incorrect such that the common conclusion that trade has contributed very little to rising income inequality needs further exploration. To see this, again consider the finding in Leamer (1996) that during the 1970s the U.S. experienced a sharp decline in the relative price of unskilled-labor-intensive products. By most measures (e.g., college-high school premium) inequality didn't rise until the 1980s. If price shocks and wage effects occur contemporaneously, then these two facts don't support the idea that trade mattered. But if the U.S. economy contains extensive frictions which prevent interindustry factor mobility for several years, then this 1970s price shock might not have generated StolperSamuelson wage effects until the 1980s. In this case trade-induced price changes might have mattered a lot. 
This discussion indicates that a full understanding of trade's effect on income inequality must address the issue of timing: how slowly does the HO clock tick? If it ticks decade by decade rather than year by year, the literature's current thinking might need revising.

Potential Limitations of Price-Index Data: What About Cones?

One final issue to consider is the inability of price-index data to identify the crucial issue of how relative factor prices depend on a country's product mix.

As discussed earlier, the SS theorem involves the prices of only those industries with current domestic production. Price changes for industries not domestically produced simply entail consumption-deflated real-wage changes for all domestic factors. Cheaper foreign t-shirts are a good thing for even less-skilled U.S. workers if no U.S. firms produce t-shirts. Whether or not the United States makes t-shirts depends on forces such as the national endowment mix and level of technology. Thus changes over time in product mixes can matter greatly for the economy's links between product prices and factor prices.

There is a potential problem with the domestic, export, and import price data used by the studies in this paper. All these data are price indexes designed to measure the prices of unchanging baskets of goods. All three series are produced by the Bureau of Labor Statistics (BLS), and the BLS Handbook of Methods (1992) details the various methods for eliminating product changes from the indexes. This is done both by selecting a fixed basket of goods to price and by systematically eliminating from transaction prices any changes due to quality changes (except in instances of "drastic" introductions and/or eliminations of products).

The price-index methodology suggests that the BLS price data tend not to reflect changes in product mixes either by domestic producers or foreign producers. Price increases because of quality upgrading get reduced while price decreases because of quality reductions get increased. Thus, there is an important tension between the theory of cones of diversification and the empirical reality of price-index construction.

How might this price problem be addressed? Alterman (1991) points out that import and export unit values that can be constructed off of Census Bureau trade-flow data do not adjust for 
quality changes. In principle, one might be able to compare BLS traded-price indexes with tradedgoods unit values to look for evidence of changing product quality. For example, if domestic producers are moving towards higher-quality products then export unit-values should rise faster than export price indexes. Indeed, Alterman does a direct comparison like this and reports the "puzzling" result that during the 1970s and 1980s BLS import price indexes tend to rise faster than the Census unit values. Alterman discusses that one might expect quality-adjusted price indexes to rise more slowly if import quality is rising over time. But thinking about different countries moving into different cones suggests an alternative view. Perhaps the average quality of U.S. imports is declining, not rising as is usually presumed, as foreign producers increasingly concentrate on unskilled-labor-intensive products. In this case quality-adjusted price indexes should rise faster than unit values, as the data actually show. Another possible solution to changing product mixes and price indexes is suggested by Feenstra (1994) who develops a methodology for adjusting import-price data to account for new product varieties.

\section{Conclusion}

This paper has attempted to provide a comprehensive survey and synthesis of research on how product-price changes have contributed to rising U.S. wage inequality. It has surveyed nine product-price studies which together demonstrate how the methodology of product-price studies has evolved. After surveying each paper individually I synthesized the findings and drew two main conclusions. The first conclusion is that this literature has refined a set empirical strategies for applying the SS theorem to the data from which important methodological lessons can be learned. The second main conclusion is that despite the methodological progress that has been made, research to date still has fundamental limitations regarding the key question of how much international trade has contributed to rising wage inequality. 
References

Alterman, William, "Price Trends in U.S. Trade: New Data, New Insights," in Peter Hooper and J. David Richardson (eds), InternationalEconomic Transactions: Issues in Measurement and Empirical Research, National Bureau of Economic Research Studies in Income and Wealth Volume 55, Chicago: The University of Chicago Press, 1991, pp. 109-143.

Baldwin, Robert E. and R. Spence Hilton, "A Technique for Indicating Comparative Costs and Predicting Changes in Trade Ratios," The Review of Economics and Statistics, February 1984, pp. 105-110.

Baldwin, Robert E. and Glen G. Cain, "Shifts in U.S. Relative Wages: The Role of Trade, Technology, and Factor Endowments," National Bureau of Economic Research Working Paper \#5934, February 1997.

Bhagwati, Jagdish, "Free Traders and Free Immigrationists: Strangers or Friends?", Russell Sage Foundation Working Paper, 1991.

Blanchard, Olivier, and Larry Katz, "Regional Evolutions," Brookings Papers on Economic Activity, 1992.

Deardorff, Alan V., "Testing Trade Theories and Predicting Trade Flows," in Ronald W. Jones and Peter B. Kenen (eds) Handbook of International Economics, Volume 1, Amsterdam: Elsevier Science Publishers B.V., 1984, pp. 467-517.

Deardorff, Alan V., "Overview of the Stolper-Samuelson Theorem," in Alan V. Deardorff and Robert M. Stern (eds) The Stolper-Samuelson Theorem: A Golden Jubilee, Ann Arbor: The University of Michigan Press, 1994, pp. 7-34.

Deardorff, Alan V. and Dalia Haikura "Trade and Wages: What Are the Questions?", in Jagdish Bhagwati and Marvin Kosters (eds) Trade and Wages: Leveling Wages Down?, Washington, D.C.: American Enterprise Institute, 1994, pp. 36-75.

Deardorff, Alan V., and Robert M. Stern (eds) The Stolper-Samuelson Theorem: A Golden Jubilee, Ann Arbor: The University of Michigan Press, 1994.

Ethier, Wilfred J., "Higher Dimensional Issues in Trade Theory," in Ronald W. Jones and Peter B. Kenen (eds) Handbook of International Economics, Volume 1, Amsterdam: Elsevier Science Publishers B.V., 1984, pp. 131-184.

Feenstra, Robert C., "New Product Varieties and the Measurement of International Prices," American Economic Review, March 1994, pp. 157-177.

Feenstra, Robert C. and Gordon H. Hanson, "Foreign Investment, Outsourcing, and Relative Wages," in Robert C. Feenstra and Gene M. Grossman (eds) Political Economy of Trade Policy: Essays in Honor of Jagdish Bhagwati, Cambridge: MIT Press, 1995.

Feenstra, Robert C. and Gordon H. Hanson, "Productivity Measurement and the Impact of Trade and Technology on Wages: Estimates For the U.S., 1972-1990," National Bureau of Economic Research Working Paper \#6052, June 1997. 
Freeman, Richard B., "Are Your Wages Set in Beijing?" Journal of Economic Perspectives, Summer 1995, pp. 15-32.

Harrigan, James, and Rita A. Balaban, "U.S. Wages in General Equilibrium: Estimating the Effects of Trade, Technology, and Factor Supplies, 1963-1991," mimeograph, September 1997.

Haskel, Jonathan and Matthew J. Slaughter, "Does the Sector Bias of Skill-Biased Technological Change Explain Changing Wage Inequality?" National Bureau of Economic Research Working Paper \#6565, May 1998.

Helpman, Elhanan, and Paul R. Krugman, Market Structure and ForeignTrade, Cambridge: MIT Press, 1985.

Krueger, Alan B., "Labor Market Shifts and The Price Puzzle Revisited," National Bureau of Economic Research Working Paper \#5924, February 1997.

Lawrence, Robert Z. and Matthew J. Slaughter, "International Trade and American Wages in the 1980s: Giant Sucking Sound or Small Hiccup?" in Martin Neil Baily and Clifford Winston (eds) Brookings Papers on Economic Activity: Microeconomics 2, 1993, 161-211.

Leamer, Edward E., "In Search of Stolper-Samuelson Effects On U.S. Wages," National Bureau of Economic Research Working Paper \#5427, January 1996.

Magee, Steven M., "Three Simple Tests of the Stolper-Samuelson Theorem," in Peter Oppenheimer (ed) Issues in International Economics, London: Oriel Press, pp. 138-153.

Sachs, Jeffrey D,. and Howard Shatz, "Trade and Jobs in U.S. Manufacturing," Brookings Papers on Economic Activity, 1994, 1-84.

United States Department of Labor, Bureau of Labor Statistics, Handbook of Methods: Bulletin \#2214, Washington, D.C.: U.S. Government Printing Office, September 1992. 


\section{Table 1}

Mandated Factor-Price Changes:

1989 through 1994

\begin{tabular}{|c|c|c|c|}
\hline $\begin{array}{l}\text { Industry } \\
\text { Sample }\end{array}$ & $\begin{array}{l}\text { Estimation } \\
\text { Method }\end{array}$ & $\begin{array}{l}\text { Nonproduction } \\
\text { Labor }\end{array}$ & $\begin{array}{l}\text { Production } \\
\text { Labor }\end{array}$ \\
\hline \multirow[t]{3}{*}{$\begin{array}{l}\text { "Finished-Processor" } \\
\text { Industries }\end{array}$} & $\overline{\mathrm{OLS}}$ & $\begin{array}{c}0.073 \\
(3.503)\end{array}$ & $\begin{array}{l}0.029 \\
(1.609)\end{array}$ \\
\hline & $\begin{array}{c}\text { WLS } \\
\text { (value of shipments) }\end{array}$ & $\begin{array}{l}0.055 \\
(2.091)\end{array}$ & $\begin{array}{c}0.036 \\
(1.793)\end{array}$ \\
\hline & $\begin{array}{c}\text { WLS } \\
\text { (employment) }\end{array}$ & $\begin{array}{c}0.071 \\
(3.278)\end{array}$ & $\begin{array}{c}0.006 \\
(0.308)\end{array}$ \\
\hline \multirow[t]{3}{*}{ All Industries } & OLS & $\begin{array}{l}0.057 \\
(2.391)\end{array}$ & $\begin{array}{c}0.058 \\
(3.714)\end{array}$ \\
\hline & $\begin{array}{c}\text { WLS } \\
\text { (value of shipments) }\end{array}$ & $\begin{array}{c}0.005 \\
(0.082)\end{array}$ & $\begin{array}{c}0.104 \\
(2.002)\end{array}$ \\
\hline & $\begin{array}{c}\text { WLS } \\
\text { (employment) }\end{array}$ & $\begin{array}{c}0.036 \\
(0.818)\end{array}$ & $\begin{array}{c}0.081 \\
(1.988)\end{array}$ \\
\hline \multirow[t]{3}{*}{$\begin{array}{l}\text { All Non-Finished- } \\
\text { Processor Industries }\end{array}$} & OLS & $\begin{array}{l}0.040 \\
(1.259)\end{array}$ & $\begin{array}{c}0.071 \\
(3.436)\end{array}$ \\
\hline & $\begin{array}{c}\text { WLS } \\
\text { (value of shipments) }\end{array}$ & $\begin{array}{c}0.007 \\
(0.098)\end{array}$ & $\begin{array}{l}0.125 \\
(1.970)\end{array}$ \\
\hline & $\begin{array}{c}\text { WLS } \\
\text { (employment) }\end{array}$ & $\begin{array}{c}0.041 \\
(0.837)\end{array}$ & $\begin{array}{l}0.115 \\
(1.999)\end{array}$ \\
\hline
\end{tabular}

Note: Mandated factor-price changes are the coefficients from a "mandated-wage" regression pooling all industries in the indicated sample to estimate product-price changes on input cost shares. See text for details. T-statistics are reported beneath each coefficient.

Data Source: NBER Productivity Data Base 
Table 2

Consistency Check of Product-Price Changes Against Skill Intensity 1978 through 1989

\begin{tabular}{|c|c|c|c|}
\hline $\begin{array}{l}\text { Industry } \\
\text { Sample }\end{array}$ & $\begin{array}{l}\text { Estimation } \\
\text { Method }\end{array}$ & $\begin{array}{l}\text { Coefficient on } \\
\text { Prod'n Share }\end{array}$ & $\begin{array}{c}\text { Coefficient on } \\
\text { Computer Dummy }\end{array}$ \\
\hline \multirow[t]{3}{*}{$\begin{array}{c}\text { All Industries, } \\
\text { No Computer Dummy }\end{array}$} & $\overline{\overline{\text { OLS }}}$ & $\begin{array}{l}-0.007 \\
(-0.594)\end{array}$ & $\overline{\text { N.A. }}$ \\
\hline & $\begin{array}{c}\text { WLS } \\
\text { (value of shipments) }\end{array}$ & $\begin{array}{c}0.008 \\
(0.813)\end{array}$ & N.A. \\
\hline & $\begin{array}{c}\text { WLS } \\
\text { (employment) }\end{array}$ & $\begin{array}{c}0.003 \\
(0.931)\end{array}$ & N.A. \\
\hline \multirow[t]{3}{*}{$\begin{array}{l}\text { All Industries, } \\
\text { Computer Dummy }\end{array}$} & OLS & $\begin{array}{c}-0.017 \\
(-2.449)\end{array}$ & $\begin{array}{c}-0.168 \\
(-69.658)\end{array}$ \\
\hline & $\begin{array}{c}\text { WLS } \\
\text { (value of shipments) }\end{array}$ & $\begin{array}{l}-0.025 \\
(-2.518)\end{array}$ & $\begin{array}{l}-0.170 \\
(-52.504)\end{array}$ \\
\hline & $\begin{array}{c}\text { WLS } \\
\text { (employment) }\end{array}$ & $\begin{array}{l}-0.031 \\
(-3.036)\end{array}$ & $\begin{array}{l}-0.173 \\
(-47.639)\end{array}$ \\
\hline
\end{tabular}

Note: Coefficient estimates are from the regression (SS) $\mathrm{P}_{\mathrm{j}}{ }^{*} 1980 \mathrm{~s}=\alpha+\beta(\mathrm{PW} /(\mathrm{PW}+\mathrm{NPW}))_{\mathrm{j}} 1980$ $+\beta_{c}\left(D_{\text {computers }}\right)+e_{j}$, estimated both with and without a dummy variable for the computer industry (SIC revision 2 industry \#3573). T-statistics are reported beneath each coefficient.

Data Source: NBER Productivity Data Base 